INTERNATIONAL JOURNAL OF MULTIDISCIPLINARY RESEARCH AND ANALYSis

ISSN(print): 2643-9840, ISSN(online): 2643-9875

Volume 05 Issue 02 February 2022

DOI: 10.47191/ijmra/v5-i2-16, Impact Factor: 6.072

Page No. $343-354$

\title{
Monitoring The Content of Heavy Metals in The Soil and Wines from Different Wine-Growing Areas of Romania
}

\author{
Petronela Anca Onache ${ }^{1,5}$, Roxana Elena lonete ${ }^{2}$, Andreea Maria lordache ${ }^{2}$, Alina Florea ${ }^{1,}$, \\ Dorin Ioan Sumedrea ${ }^{1}$, Marina Iliescu ${ }^{3}$, Doina Damian ${ }^{4}$, Răzvan Filimon ${ }^{4}$, Ovidiu TITA ${ }^{5}$, Andrei \\ Tanase $^{1}$
}

${ }^{1}$ National Research and Development Institute for Biotechnology in Horticulture Stefanesti - Arges, Romania, Street BucurestiPitesti no 37, 117715

${ }^{2}$ National Research and Development Institute for Cryogenics and Isotopic Technologies - ICSI Rm. Valcea, Râmnicu Vâlcea, Romania, Street Uzinei no 4, 240050

${ }^{3}$ Research and Development Station for Viticulture and Vinification Blaj, Romania, Str Gh.Baritiu, No2, 515400, Alba County

${ }^{4}$ Research Station and Development for Viticulture and Vinification Iaşi, Romania, Str Mihail Sadoveanu no. 48, 700489

${ }^{5}$ Lucian Blaga" Sibiu University, Romania, Str. Ion Raţiu, No.5-7, 550012

\begin{abstract}
Determination of heavy metals in soil and wine is very important for wine quality and consumer health, but at the same time it is a complementary tool for differentiating wines according to their geographical origin. In this work, soils and ten brands of wines originated from four major wine-growing areas of Romania (laşi, Babadag, Ştefăneşti and Blaj) were considered for performing a multielement ( $\mathrm{Cr}, \mathrm{Ni}, \mathrm{Cu}, \mathrm{As}, \mathrm{Pb}, \mathrm{Hg}, \mathrm{V}, \mathrm{Sr}, \mathrm{Mn}, \mathrm{Zn}, \mathrm{Fe})$ investigation in order to assess regional specificity. Heavy metals found in the investigated wines were below the limits imposed by European standards (O.I.V.) the elements concentrations following the trend: $\mathrm{Zn}>\mathrm{Fe}>\mathrm{Mn}>\mathrm{Sr}>\mathrm{Ni}>\mathrm{Cr}>\mathrm{Cu}>\mathrm{Pb}>\mathrm{V}>\mathrm{Hg}>\mathrm{As}$. For the soils analyzed, the heavy metals content was found to be below the maximum permitted limit, except for $\mathrm{Cu}(135.45 \mathrm{mg} / \mathrm{kg})$ from the laşi vineyard, which was at the permitted limit. The high values obtained for copper may be the result of different treatments with the Bordelaise solution for the vine. The elements $\mathrm{CA}, \mathrm{Mn}$ and $\mathrm{Hg}$ observed from the research that they are predominantly of natural origin. Based on our results, a distinction has been made between wines according to their geographical origin, considering that the specific elements of discrimination $\mathrm{Sr}, \mathrm{Pb}$, and $\mathrm{Ni}$ for the Stefănesti vineyard (Muntenia region), $\mathrm{Cr}$ and $\mathrm{Hg}$ for the Babadag vineyard (Dobrogea region), Sr and $\mathrm{V}$ for the laşi vineyard (region of Moldova), respectively Fe and $\mathrm{Zn}$ for the Blaj vineyard (Transilvania region).
\end{abstract}

KEYWORDS: Wine, soil, heavy metals, ICP-MS, HR-CS-AAS, wine-growing area

\section{INTRODUCTION}

Obtaining wine was one of the oldest occupations of the Romanians, reaching the time of the dacians and romans. Wine was among the first alcoholic beverages produced and the most widespread in Romania. A special importance was reserved for the classification of wines by varieties, geographical areas and years of production. (Arvanitoyannis et al, 1999; Serrano-Lourido et al, 2012; Boschetti et al., 2013; Košir et al, 2014; Dugo et al, 2015). Most illegalities at wines are made by declaring some wines being obtained from noble and pure grape cultivars. The wines can be obtained by blending from various grape cultivars; therefore a special importance is manifested for the classification and identification of wine varieties (Huang et al, 2017).

Research into the evaluation of the authenticity of food products has increased in recent years and particular attention is paid to their quality and composition. Evaluation of these products involves the determination of food characteristics such as nutritional parameters, shelf life and healthiness (Woldemariam et al, 2011; Danezis et al, 2016; Zava et al, 2020). Due to food fraud, which can have a negative impact on human health and the economic market, producers and ordinary consumers have understood the benefits of protecting traditional or appreciated products (Everstine et al, 2013).

In order to identify the important compounds for the fingerprinting of the wine, it is done through the instrumental analysis. (Héberger et al, 2003; Franquet-Griell et al, 2004; Kiss et al, 2005; Regmi et al, 2012; De Villiers et al, 2012; Fabani et al, 2013; Huang et al, 2017) But lately, advanced analysis methods have used, such as the use of electronic tongues (Cetó et al, 2012) and 


\section{Monitoring The Content of Heavy Metals in The Soil and Wines from Different Wine-Growing Areas of Romania}

chemical sensors (Gallagher et al, 2012). Various statistical analysis methods were used to characterize the wine, such as the analysis of elementary compounds in wine by PCA, the discriminant linear analysis (LDA) and the analysis of groups of elements (HCA). (Arvanitoyannis et al, 1999).

The important factors in the production and marketing of wine are authenticity and geographical origin. Various advanced analysis methods to identify the geographical origin of the wine were used, such as atomic absorption spectroscopy (AAS) or inductively coupled plasma mass spectrometry (ICP-MS) (Almeida \& Vasconcelos, 2003; Goamez et al, 2004; Coetzee et al, 2005; Geana et al, 2013).

Environmental, soil and climate factors are important in characterizing grape varieties and wines in terms of quality, quantity and flavor. (Bora, 2015). Environmental factors are the region, pedology, climate, soil type and composition (Kostic et al, 2010; Fiket et al, 2011; Huzum et al, 2012). Production factors, including: fertilizer and pesticide use, industrial pollution, wine transport and storage are anthropogenic factors leading to the pollution of vineyards (Tariba et al, 2011; Bora et al, 2015).

At present, vineyards are contaminated and still polluted, so that the heavy metal content of vineyards soils can lead to serious problems in plant productivity, food quality and endanger human health (Bora et al, 2015; Zava et al, 2020). Certain metals such as $\mathrm{Fe}, \mathrm{Cu}$ and $\mathrm{Zn}$ are essential in the biological development of plants and other metals are extremely toxic even if they are in small quantities, such as Pb, As, Ni, Cr, Hg, V, Co, Mo and Cd (Gogoaşă et al, 2005; Tuzen, 2007; Geană et al, 2013).

For the origin of wines the most researched and determined heavy metals are: $\mathrm{Fe}, \mathrm{Rb}, \mathrm{Cu}, \mathrm{Cr}, \mathrm{Co}, \mathrm{Sb}, \mathrm{Cs}, \mathrm{As}, \mathrm{Ag}, \mathrm{Li}, \mathrm{Sr}, \mathrm{Al}$ and $\mathrm{Mn}$ (Fiket et al, 2011; Geană et al, 2013; Bora et al, 2015). In Romania according to this research the most important heavy metals used to determine the geographical origin of wines are $\mathrm{Mn}$ and Sr (Geană et al, 2013). In this work an investigation of heavy metal content profile ( $\mathrm{Cr}, \mathrm{Ni}, \mathrm{Cu}, \mathrm{As}, \mathrm{Pb}, \mathrm{Hg}, \mathrm{V}, \mathrm{Sr}, \mathrm{Mn}, \mathrm{Zn}$ and $\mathrm{Fe}$ ) of soil from four important Romanian vineyards and some wine brands of Muntenia (Stefanesti wine-growing area), Dobrogea (Babadag vineyard), Transilvania (Blaj wine-growing area) and Moldova (lasi wine-growing area) regions is performed in an attempt to achieve an overview on the heavy metals profile and to differentiate wines by regions. For the classification of wines according to geographical origin, a multiple items analysis was applied in combination with statistical modelling of multi-output data.

\section{MATERIALS AND METHODS}

The study is carried out in four different geographical locations in Romania, on ten assortments of wine (Chardonnay and Fetească Neagră from Babadag vineyard - Dobrogea region; Fetească Albă and Cabernet Sauvignon from lasi wine-growing area Moldova region; Muscat Ottonel and Traminer Roz from Blaj wine-growing area - Transilvania region; respectively Fetească Albă, Riesling Italian, Fetească Regală, and Burgund from - and Stefanesti wine-growing area - Muntenia region) from the harvest of 2019. The coordinates for each studied geographical area are: wine centre lasi $-47^{\circ} 12 \times 42,5^{\prime \prime} \mathrm{N}, 27^{\circ} 311^{\circ} 7,1^{\prime \prime} \mathrm{E}, 120 \mathrm{~m}$ altitude, East exposure, the European road E 85 passes through county, at $12 \mathrm{~km}$ from the wine-growing area; Blaj wine-growing area $46^{\circ} 18 ` 51,2^{\prime \prime} \mathrm{N}, 23^{\circ} 92^{4} 40,5^{\prime \prime} \mathrm{E}, 278 \mathrm{~m}$ altitude, East exposure, the European road E 81 and highway A10 passes through county, at $23 \mathrm{~km}$ from the wine-growing area; Ştefăneşti wine-growing area - $44^{\circ} 51^{\prime} \mathrm{N}$ si $24^{\circ} 57^{\prime} \mathrm{E}$, altitude $250 \mathrm{~m}$, South exposure, the highway A1 passes through county, at $5 \mathrm{~km}$ from wine-growing area, and Babadag vineyard $-44^{\circ} 53^{\prime} 36^{\prime \prime} \mathrm{N} 28^{\circ} 42^{\prime} 43^{\prime \prime} \mathrm{E}$, altitude $250 \mathrm{~m}$, east exposure the European road E 87 passes through county, at $5 \mathrm{~km}$ from the vineyard (Figure 1).

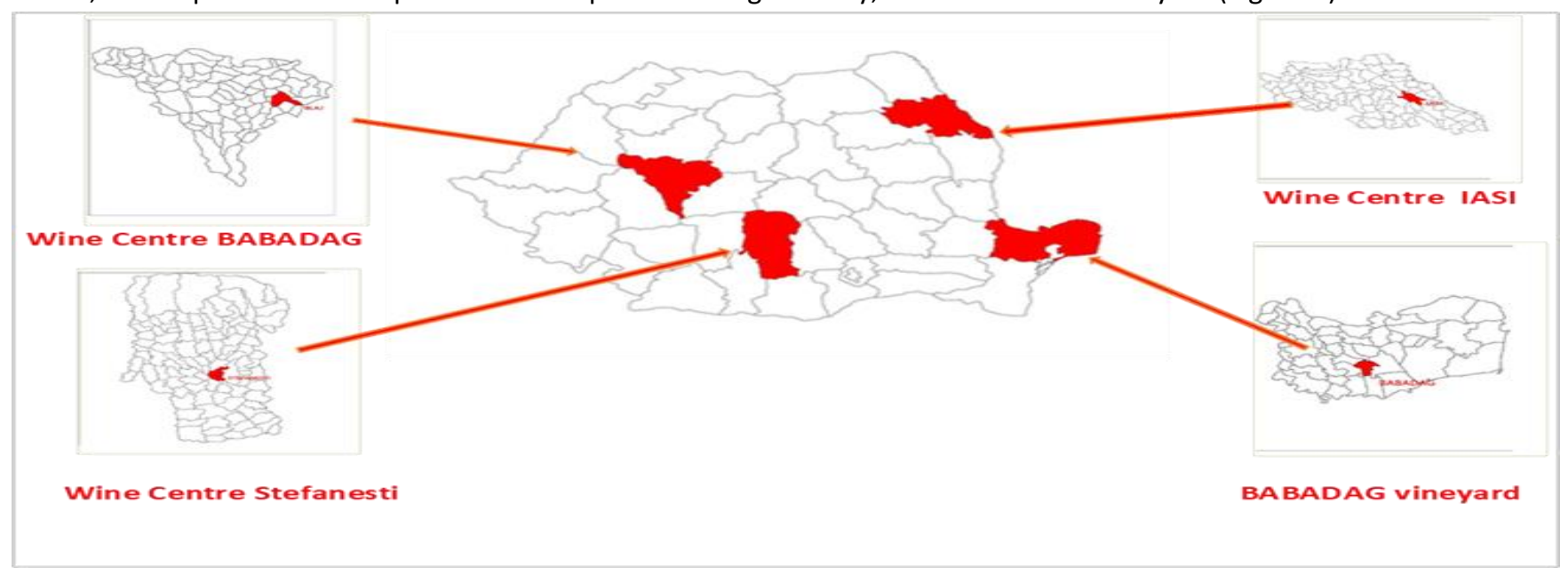

Figure 1 .Location of the study areas for the analyzed wines

The characteristics of soils in the areas studied are: lasi wine-growing area have salnic cernoziom soil, wine Blaj wine-growing area have soil with clay and with sarmatian marl content and Babadag vineyard have sand - clay medium clay, yellowish brown 


\section{Monitoring The Content of Heavy Metals in The Soil and Wines from Different Wine-Growing Areas of Romania}

soil. The soil in Ştefăneşti wine-growing centre is of the class umbrisoils of eutricambosoil type, brown, typical eumezobasic with clay in situ; the texture of the soil is clay-sandy, clay-clay, without skeleton, and the soil tillage is done with plows, the mechanical presses at intervals, the manual hoeing in a row (Toti, 2017). In 2019, during the growing season temperatures were specific to the areas studied, a longer autumn and spring was observed. In these area autumn and winter is dry, while during winter quite high temperature were registered in recent years.

Prior to analyses by ICP-MS, the wine samples have to be carefully decomposed. The amount of $1.0 \mathrm{~g}$ of wine was digested using A closed iPrep vessels speed iwaveJ system MARS6 CEM One Touch (CEM Corporation, Matthews, North Carolina, USA) with concentrated acid (10 $\mathrm{ml}$ of HNO3 69\%) according to a 2 steps temperature-controlled digestion program. Each resulted clear aliquot of the digest were quantitatively transferred to $25 \mathrm{ml}$ volumetric flasks and filled to volume with ultrapure water.

For soils, an amount of $0.5 \mathrm{~g}$ was digested using the same closed iPrep vessels speed iwaveJ system MARS6 CEM One Touch (CEM Corporation, Matthews, North Carolina, USA) with the mixture of concentrated acids (10 ml of HNO3 69\% $1 \mathrm{ml} \mathrm{HCl} 37 \%$ ) according to a 2 steps temperature-controlled digestion program. The resulted sediment digests were quantitatively transferred to $50 \mathrm{ml}$ volumetric flasks and filled to volume with ultrapure water.

Analytical determinations of elements $\mathrm{Cr}, \mathrm{Ni}, \mathrm{Cu}, \mathrm{As}, \mathrm{Pb}, \mathrm{Hg}, \mathrm{V}, \mathrm{Sr}, \mathrm{Mn}, \mathrm{Zn}$ and Fe were performed using an inductively coupled plasma mass spectrometer ICP-QMS 820-MS (Varian, Melbourne, Australia) equipped with an SPS-3 autosampler (Varian, Malgrave, Australia) and collision-reaction interface iCRI working in $\mathrm{H} 2$ and He modes. The optimal conditions were as follows: $\mathrm{RF}$ power of $1200 \mathrm{~W}$, plasma gas-flow rate of $12 \mathrm{~L} / \mathrm{min}$, auxiliary gas-flow rate of $1.5 \mathrm{~L} / \mathrm{min}$, nebulizer gas-flow rate of $1.05 \mathrm{~L} / \mathrm{min}$, $\mathrm{H} 2$ gas flow rate of $90 \mathrm{~mL} / \mathrm{min}$, He gas flow of $90 \mathrm{~mL} / \mathrm{min}$ and a dwell time of $50 \mathrm{~ms}$ for each isotope and 209Bi, 6Li, 45Sc, 159Tb, $89 \mathrm{Y}$ isotopes that served as internal standards. Blank samples were also prepared by following the analytical methodology mentioned above. These solutions were analysed by ICP-MS after appropriate dilution using external standards for calibration, considering five points on the curve and one for quality control. Calibration standard solutions and internal standards were prepared by successive dilution of a high purity ICP multi-element calibration standard ( $10 \mathrm{\mu g} / \mathrm{L}$ from twenty-nine elemental ICPMS standards, matrix: 5\% HNO3, Perkin Elmer Life and Analytical Sciences) and a mono-elemental calibration standard (10 $\mu \mathrm{g} / \mathrm{L}$ $\mathrm{Hg}$, matrix 5\% HNO3, Perkin Elmer Life and Analytical Sciences).

Concentration of the compounds was evaluated by statistical methods. Authentication of the geographical origin of wines using multi-element analyses with multivariate was evaluated by statistical modelling. For the statistical interpretation of the results, the data were included in an Excel database and then statistically interpreted with the SPSS 14.0 program, and the comparison of means was performed with the Duncan's multiple range test at $5 \%$ statistical assurance. The assessment of the degree of contamination / pollution of the soil-plant system, the results obtained were compared with the reference values provided by Order no. 756/1997 of the Minister of Waters, Forests and Environmental Protection, in the case of soil, and the values obtained in the case of wine analysis were reported to the Law on Vine and Wine but also to the regulations stipulated in O.I.V.

\section{RESULTS AND DISCUSSION}

Quantitative determinations for soil samples were made for 9 micro-elements $\mathrm{Cr}, \mathrm{Ni}, \mathrm{Cu}, \mathrm{As}, \mathrm{Pb}, \mathrm{Hg}, \mathrm{V}, \mathrm{Ag}, \mathrm{Sr}$ and 3 macroelements $\mathrm{Mn}, \mathrm{Zn}$, Fe. Comparison of the $\mathrm{Cr}, \mathrm{Cu}$, and as level in the studied soils was performed with the Duncan's multiple range test at significance level $a=0.05(P \leq 0.05)$. There is a rather large difference in the soil from lasi wine-growing area versus the other regions as concern the $\mathrm{Cu}(135,455 \mathrm{mg} / \mathrm{kg})$, but also for $\mathrm{Cr}(34,002)$. Equally high values are found on the soil of Stefanesti wine-growing area for the $\mathrm{Cr}$ metal $(48,343)$. The lowest values of these metals are found on the soil of Babadag vineyard. In table 1 can be seen that the values of the analyzed indicators are very different from one region to another and different statistically significantly for an insurance level of $5 \%$. The distribution of copper from the analyzed soils is differentiated, namely: the soil from Stefănești vineyard $(5,430 \mathrm{mg} / \mathrm{kg})$ recorded the highest concentrations, at the opposite pole with the lowest concentrations were recorded in the soils of lasi Vineyard, the differences between them being statistically assured. The variation range of the As concentration in the soils was between the maximum value of $0.888 \mathrm{mg} / \mathrm{kg}$ registered in the soils from Stefanești, followed by $0.608 \mathrm{mg} / \mathrm{kg}$ - the soils from Blaj, $0.453 \mathrm{mg} / \mathrm{kg}$ - the soils from the lasi area, and $0.028 \mathrm{mg} / \mathrm{kg}$ in Babadag soils, the differences between them being significant for an insurance level of $5 \%$. 
Monitoring The Content of Heavy Metals in The Soil and Wines from Different Wine-Growing Areas of Romania

Table 1. The Level of $\mathrm{Cr}$, Cu, As Elements in the Soils Studied

\begin{tabular}{|l|r|r|r|r|r|r|}
\hline Soil & Crmg/kg & $\begin{array}{l}5 \% \text { least } \\
\text { significant } \\
\text { difference }\end{array}$ & Cu mg/kg & $\begin{array}{l}5 \% \text { least } \\
\text { significant } \\
\text { difference }\end{array}$ & As m/kg & $\begin{array}{l}5 \% \text { least } \\
\text { significant } \\
\text { difference }\end{array}$ \\
\hline Sol Stefanesti & $48.343 \mathrm{a}$ & 1.000 & $5.430 \mathrm{~b}$ & 1.000 & $0.888 \mathrm{a}$ & 1.000 \\
\hline Soil Babadag & $0.148 \mathrm{~d}$ & 1.000 & $0.120 \mathrm{~d}$ & 1.000 & $0.028 \mathrm{~d}$ & 1.000 \\
\hline Soil Blaj & $14.447 \mathrm{C}$ & 1.000 & $3.578 \mathrm{c}$ & 1.000 & $0.608 \mathrm{~b}$ & 1.000 \\
\hline Soil lasi & $34.002 \mathrm{~b}$ & 1.000 & $135.455 \mathrm{a}$ & 1.000 & $0.453 \mathrm{C}$ & 1.000 \\
\hline
\end{tabular}

*Values with different letters are statistically different at $5 \%$ probability, Duncan test

In table 2 analyses the $\mathrm{V}, \mathrm{Sr}$ and $\mathrm{Pb}$ elements using Duncan's multiple range test. Is observed a very high value in the content of $\mathrm{Pb}$ in the soil of the wine centre Blaj $(19,76 \mathrm{mg} / \mathrm{kg})$, the other wine-growing centers have a lower content of $\mathrm{Pb}$ in the soil, the differences between the values being statistically assured. According to the analysed data the Sr content of the soil has values close in the Stefanesti and lasi wine-growing area (with values between $30-34,636 \mathrm{mg} / \mathrm{kg}$ ), but statistically different. The lowest value is found to Babadag vineyard $(0,089 \mathrm{mg} / \mathrm{kg})$, followed by the wine centre Blaj $(15,276 \mathrm{mg} / \mathrm{kg})$.

The highest content of $V$ in the soil was registred at the wine centre Ștefănești $(53,491 \mathrm{mg} / \mathrm{kg})$ and the lowest in the soil of Babadag wine growing area $(0,178 \mathrm{mg} / \mathrm{kg})$.

Table 2. THE LEVEL OF V, SR AND PB ELEMENTS IN THE SOILS STUDIED

\begin{tabular}{|c|c|c|c|c|c|c|}
\hline Soil & $\mathrm{V} \mathrm{mg} / \mathrm{kg}$ & $\begin{array}{c}5 \% \text { least } \\
\text { significant } \\
\text { difference }\end{array}$ & $\mathrm{Sr} \mathbf{m g} / \mathrm{kg}$ & $\begin{array}{l}5 \% \text { least } \\
\text { significant } \\
\text { difference }\end{array}$ & $\mathrm{Pb} \mathrm{m} / \mathrm{kg}$ & $\begin{array}{l}5 \% \text { least } \\
\text { significant } \\
\text { difference }\end{array}$ \\
\hline Sol Stefanesti & 53.491 a & 1.000 & 34.636 a & 1.000 & 4.655 & 0.058 \\
\hline Soil Babadag & $0.178 d$ & 1.000 & $0.089 \mathrm{~d}$ & 1.000 & 4.367 & 0.058 \\
\hline Soil Blaj & $18.816 \mathrm{c}$ & 1.000 & $15.276 \mathrm{c}$ & 1.000 & 19.760 a & 1.000 \\
\hline Soil lasi & 37.509 b & 1.000 & $30.627 \quad b$ & 1.000 & $5.073 \mathrm{~b}$ & 1.000 \\
\hline
\end{tabular}

*Values with different letters are statistically different at $5 \%$ probability, Duncan test

In Table 3 showed although the values of $\mathrm{Hg}$ content in the soil are close, but differences between them are statistically significant within the geographical areas studied, the highest value being in the Blaj region. $(0,052 \mathrm{mg} / \mathrm{kg} \mathrm{Hg})$ and the lowest values were highlighted in the soils of Babadag and Stefănești $(0.043 \mathrm{mg} / \mathrm{kg}, 0.045 \mathrm{mg} / \mathrm{kg} \mathrm{Hg}$, respectively). In the case of Ni, the lowest value is found on the soil from Babadag vineyard $(0,046 \mathrm{mg} / \mathrm{kg})$, and the highest were highlighted in Stefanesti and Blaj wine-growing area $(3,561 \mathrm{mg} / \mathrm{kg}, 3,565 \mathrm{mg} / \mathrm{kg}$ respectively, table 3), the differences between them being statistically assured. Comparing the nickel concentration to the national legislation in force, it can be seen that it is within the normal permissible limits (20 mg / kg), and it is not possible to speak in the case of these vineyards as being polluted with Ni (Bora, 2019).

Table 3. THE LEVEL OF HG AND NI METALS IN THE SOILS STUDIED

\begin{tabular}{|l|rr|r|r|r|r|}
\hline Soil & Hg mg/mg & $\begin{array}{l}\text { 5\% least } \\
\text { significant } \\
\text { difference }\end{array}$ & Ni mg/kg & $\begin{array}{l}5 \% \text { least } \\
\text { significant } \\
\text { difference }\end{array}$ \\
\hline Soil Stefanesti & 0.045 & c & 0.497 & 3.561 & a & 0.221 \\
\hline Soil Babadag & 0.043 & c & 0.497 & 0.046 & c & 1.000 \\
\hline Soil Blaj & 0.052 & a & 1.000 & 3.565 & a & 0.221 \\
\hline Soil lasi & 0.046 & b & 1.000 & 3.286 & $b$ & 1.000 \\
\hline
\end{tabular}

*Values with different letters are statistically different at $5 \%$ probability, Duncan test

In the case of $\mathrm{Zn}$ and $\mathrm{Mn}$ content in the soil, their values are very small for all areas studied and differ statistically significantly between each studied geographic area. As far as Fe is concerned, the lowest content is found in the soil of Babadag vineyard, and the highest content was highlighted in the Blaj vineyard, the differences between them being statistically insured (Table 4). 
Approximate values of Fe content in the soil were recorded in the Babadag and lasi wine-growing area, including in the same class of statistical homogeneity for an insurance level of $5 \%(13,918 \mathrm{mg} / \mathrm{kg}$, respectively $13,605 \mathrm{mg} / \mathrm{kg})$.

Table 4. THE LEVEL OF FE, MN AND ZN METALS IN THE SOILS STUDIED

\begin{tabular}{|c|c|c|c|c|c|c|}
\hline Soil & $\mathrm{Fe} \mathrm{mg/kg}$ & $\begin{array}{c}5 \% \text { least } \\
\text { significant } \\
\text { difference }\end{array}$ & Mn mg/kg & $\begin{array}{c}5 \% \text { least } \\
\text { significant } \\
\text { difference }\end{array}$ & $\mathrm{Zn} \mathrm{mg/kg}$ & $\begin{array}{l}5 \% \text { least } \\
\text { significant } \\
\text { difference }\end{array}$ \\
\hline Soil Stefanesti & 3.968 & 0.222 & 546.810 a & 1.000 & 397.500 a & 1.000 \\
\hline Soil Babadag & 13.918 & 1.000 & $489.520 \mathrm{~b}$ & 1.000 & $333.600 \mathrm{~b}$ & 1.000 \\
\hline Soil Blaj & 14.552 & 1.000 & $450.670 \mathrm{c}$ & 1.000 & $305.800 \mathrm{c}$ & 1.000 \\
\hline Soil lasi & 13.605 & 0.222 & $407.530 \mathrm{~d}$ & 1.000 & $299.900 \mathrm{~d}$ & 1.000 \\
\hline
\end{tabular}

*Values with different letters are statistically different at 5\% probability, Duncan test

In table 5 is expresses the content of $\mathrm{Cr}$, $\mathrm{Cu}$ and As elements from 10 wine varieties, of the four geographic areas subject to the study. The highest $\mathrm{Cr}$ content meets in the Chardonnay wine in Babadag vineyard, and the smallest concentrations in red wine varieties in lasi and Stefanesti wine-region (Cabernet Sauvignon - 13,15 $\mu \mathrm{g} / \mathrm{l}$ and Burgund - 15,88 $\mu \mathrm{g} / \mathrm{l}$ ).

The content of wine may also depend on the treatments given to vines (Ivanova et al., 2013, Bora et al., 2015). The highest value of the contents meets at the Feteasca Neagra from Babadag vineyard (454,895 $\mu \mathrm{g} / \mathrm{l})$ and the smallest content in Feteasca Alba wine from Stefanesti vineyard $(8,635 \mu \mathrm{g} / \mathrm{l})$. In the case of As content, the highest values, but which do not differ statistically significantly, were highlighted in the Feteasca Regala and Riesling wines, both from the Ştefăneşti region. All other wines have registered lower values regardless of the wine-region (Table 5).

Table 5. THE LEVEL OF CR, CU AND AS METALS IN THE WINES ANALYZED

\begin{tabular}{|c|c|c|c|c|c|c|}
\hline Wine names & $\mathrm{Cr} \mu \mathrm{g} / \mathrm{L}$ & $\begin{array}{c}5 \% \text { least } \\
\text { significan } \\
t\end{array}$ & $\mathrm{Cu} \mu \mathrm{g} / \mathrm{L}$ & \begin{tabular}{|c|}
$5 \%$ least \\
significant \\
difference
\end{tabular} & As $\mu g / L$ & $\begin{array}{c}5 \% \text { least } \\
\text { significant } \\
\text { difference }\end{array}$ \\
\hline Chardonnay, Babadag & 270.610 & 0.073 & $120.345 \mathrm{~cd}$ & 0.156 & $1.808 \mathrm{c}$ & 0.163 \\
\hline Feteasca Neagra, Babadag & $151.170 \mathrm{c}$ & 0.067 & \begin{tabular}{|l|l|}
454.895 & $a$ \\
\end{tabular} & 1.000 & 2.394 bc & 0.360 \\
\hline Feteasca Alba,Iasi & $192.885 \mathrm{ab}$ & 0.147 & $283.110 \mathrm{bc}$ & 0.253 & $2.488 \mathrm{bc}$ & 0.360 \\
\hline Cabernet Sauvignon, Iasi & $13.510 \mathrm{e}$ & 0.067 & 60.125 ef & 0.133 & 2.544 bc & 0.360 \\
\hline Muscat ottonel, Blaj & $267.780 a b$ & 0.153 & $123.775 \mathrm{~cd}$ & 0.156 & $1.506 \mathrm{c}$ & 0.163 \\
\hline Traminer roz, Blaj & $50.370 \mathrm{~d}$ & 1.000 & $405.945 \mathrm{ab}$ & 0.177 & $1.046 \mathrm{~d}$ & 1.000 \\
\hline Feteasca Alba,Stefanesti & 175.400 bc & 0.147 & $8.635 \mathrm{f}$ & 1.000 & $4.312 \mathrm{~b}$ & 0.197 \\
\hline Burgud, Stefanesti & $15.880 \mathrm{e}$ & 0.067 & $53.395 \mathrm{e}$ & 0.133 & $3.750 \mathrm{~b}$ & 0.197 \\
\hline Riesling, Stefanesti & 187.665 bc & 0.147 & $312.650 \mathrm{~b}$ & 0.191 & $7.674 a$ & 0.433 \\
\hline Feteasca Regala, Stefanesti & $19.855 \mathrm{e}$ & 0.067 & $109.119 \mathrm{~cd}$ & 0.156 & 8.540 a & 0.433 \\
\hline
\end{tabular}

*Values with different letters are statistically different at $5 \%$ probability, Duncan test

In table 6 , the $V$ element is distinguished by a very high concentration in white wine varieties in Ştefăneşti (Riesling - 468,864 4 g/l and Feteasca Regala - $464.79 \mu \mathrm{g} / \mathrm{l})$, the other wines fall between values 23,38 $\mu \mathrm{g} / \mathrm{l}$ Burgund from Stefanesti wine center and $43.58 \mu \mathrm{g} / \mathrm{I}$ for Feteasca Alba variety from lasi wine-centre. The Sr content of the analysed wines is among the only element that determines the geographical origin of wines. The largest concentration is at the wine of Feteasca Regala from lasi wine-center and the lowest concentration of Riesling wine from Ştefăneşti wine-center, expressed for white wines; in red wines, the highest concentration of $\mathrm{Sr}$ is located at the Feteasca Regala from Babadag vineyard and the lowest in Cabernet Sauvignon wine from the lasi region. 
Monitoring The Content of Heavy Metals in The Soil and Wines from Different Wine-Growing Areas of Romania

Table 6. THE LEVEL OF V, SR AND PB METALS IN THE WINES ANALYSED

\begin{tabular}{|c|c|c|c|c|c|c|}
\hline Wine names & $V \mu g / L$ & $\begin{array}{c}5 \% \text { least } \\
\text { significan } \\
t\end{array}$ & $\mathrm{Sr} \mu \mathrm{g} / \mathrm{L}$ & $\begin{array}{c}5 \% \text { least } \\
\text { significan } \\
t\end{array}$ & $\mathrm{~Pb} \mu \mathrm{g} / \mathrm{L}$ & \begin{tabular}{c|}
$5 \%$ least \\
significant \\
difference
\end{tabular} \\
\hline Chardonnay, Babadag & $28.646 \mathrm{c}$ & 0.849 & $367.0 \mathrm{~d}$ & 0.283 & $9.980 \mathrm{~d}$ & 0.650 \\
\hline Feteasca Neagra, Babadag & $28.78 \mathrm{c}$ & 0.849 & $678.1 \mathrm{bc}$ & 0.167 & $24.990 \mathrm{abc}$ & 1.470 \\
\hline Feteasca Alba,Iasi & \begin{tabular}{|l|l|}
43.58 & $b$ \\
\end{tabular} & 0.058 & \begin{tabular}{|l|l|}
993.3 & $a$ \\
\end{tabular} & 0.052 & 37.770 a & 0.195 \\
\hline Cabernet Sauvignon, lasi & $26.440 \mathrm{c}$ & 0.849 & $352.1 \mathrm{e}$ & 1.000 & $21.540 \mathrm{de}$ & 0.235 \\
\hline Muscat ottonel, Blaj & $28.020 \mathrm{c}$ & 0.849 & 887.9 & 0.052 & 10.540 ef & 0.230 \\
\hline Traminer roz, Blaj & $23.244 \mathrm{c}$ & 0.849 & 430.6 & 0.238 & 28.580 ab & 0.280 \\
\hline Feteasca Alba,Stefanesti & $31.284 \mathrm{bc}$ & 0.220 & $379.8 \mathrm{~d}$ & 0.283 & $4.055 \mathrm{~g}$ & 1.000 \\
\hline Burgud, Stefanesti & $23.38 \mathrm{c}$ & 0.058 & 604.3 bc & 0.450 & $24.665 \mathrm{de}$ & 0.235 \\
\hline Riesling, Stefanesti & 468.864 a & 0.162 & 801.2 ab & 0.143 & 28.150 bc & 0.162 \\
\hline Feteasca Regala, Stefanesti & \begin{tabular}{|l|l|}
464.79 & a \\
\end{tabular} & 0.162 & $579.6 \mathrm{~cd}$ & 0.359 & $24.556 \mathrm{de}$ & 0.235 \\
\hline
\end{tabular}

*Values with different letters are statistically different at $5 \%$ probability, Duncan test

The $\mathrm{Pb}$ content of wines depends on the geographical area, pollution on national roads and highways near vineyards and also by the industrial areas in the vicinity of the studied vineyards (Ivanova et al., 2013; Bora et al., 2015). The highest value of the Pb content meets in Feteasca Alba wine from lasi region $(37,77 \mu \mathrm{g} / \mathrm{l})$ and the lowest values in Chardonnay wine $(9,98 \mu \mathrm{g} / \mathrm{l})$ of Babadag vineyard and Feteasca Alba wine $(4,055 \mu \mathrm{g} / \mathrm{l})$ from the Stefanesti region. Based on the applied statistical analyzes, it can be seen that there are very significant differences between the analyzed variants (Table 6).

The $\mathrm{Hg}$ content of the wine is given by the diffuse, natural movement of the traces of metal elements in the soil (Catarino et al., 2006; Ivanova et al., 2013; Gheşeş et al., 2013; Bora et al., 2015; Zava and Cone., 2015; 2020), (Table 7). The Ni content of the wine is given the "natural" mineral content of the soil and the ability of vines to absorb and accumulate these elements in grape grains, products used in the agricultural practice or winemaking treatments. (Alkıs Mert et al, 2014; Bora et al, 2015). The highest content in the element is found in Cardonnay wine $(298,945 \mu \mathrm{g} / \mathrm{l})$ of Babadag vineyard and the lowest in Feteasca Alba $(3,465 \mu \mathrm{g} / \mathrm{l})$ from Ştefăneşti wine-center the differences between them being statistically assured (table 7).

Table 7. THE LEVEL OF HG AND NI METALS IN THE WINES ANALYSED

\begin{tabular}{|c|c|c|c|c|}
\hline $\mathbf{W}$ ine names & $\mathrm{Hg} \mu \mathrm{g} / \mathrm{L}$ & $\begin{array}{l}5 \% \text { least } \\
\text { significant } \\
\text { difference }\end{array}$ & Ni $\mu g / L$ & $\begin{array}{c}\mathbf{5 \%} \text { least } \\
\text { significant } \\
\text { difference }\end{array}$ \\
\hline Chardonnay, Babadag & 7.445 & 1.000 & 298.945 & 1.000 \\
\hline Feteasca Neagra, Babadag & $5.580 \mathrm{~b}$ & 0.133 & 40.505 & 0.303 \\
\hline Feteasca Alba,lasi & $5.335 \mathrm{bc}$ & 0.217 & 123.255 & 0.203 \\
\hline Cabernet Sauvignon, lasi & $4.920 \mathrm{bc}$ & 0.271 & $46.115 \mathrm{~cd}$ & 0.149 \\
\hline Muscat ottonel, Blaj & $4.490 \mathrm{~cd}$ & 0.178 & 104.515 bc & 0.267 \\
\hline Traminer roz, Blaj & $4.690 \mathrm{bc}$ & 0.217 & 67.915 bc & 0.267 \\
\hline Feteasca Alba,Stefanesti & $4.430 \mathrm{~d}$ & 0.083 & 3.465 f & 0.344 \\
\hline Burgud, Stefanesti & $4.430 \mathrm{~d}$ & 0.083 & 7.405 ef & 0.429 \\
\hline Riesling, Stefanesti & 4.375 & 0.083 & 12.120 & 0.512 \\
\hline Feteasca Regala, Stefanesti & $4.350 \mathrm{~d}$ & 0.083 & $29.950 \mathrm{~d}$ & 0.512 \\
\hline
\end{tabular}

*Values with different letters are statistically different at $5 \%$ probability, Duncan test

The content of Fe in wine is given by wine production technology and the treatments given to vines (Jakubowski et al, 1999; di Paola-Naranjo et al, 2011; Grindlaya et al, 2011; Bora et al, 2015). The wine with the highest concentration of Fe is in Muscat Ottonel wine (12.309 mg / I) from the Blaj vineyard. According to the analysed data, the Mn content is given by the natural concentration in soil, and $\mathrm{Zn}$ content is given by the industrial area in the vicinity of the studied vineyards Table 8 . The highest $\mathrm{Zn}$ content it is in Muscat Ottonel wine $(10,041 \mathrm{mg} / \mathrm{l})$ from Blaj wine region and the smallest concentration from Ştefăneşti winecenter in Fetească Regala wine $(2,182 \mathrm{mg} / \mathrm{l})$. 
Monitoring The Content of Heavy Metals in The Soil and Wines from Different Wine-Growing Areas of Romania

Table 8. THE LEVEL OF HG AND NI METALS IN THE WINES ANALYSED

\begin{tabular}{|c|c|c|c|c|c|c|}
\hline Wine names & $\mathrm{Fe} \mathrm{mg/L}$ & \begin{tabular}{|c|}
$\mathbf{5 \%}$ least \\
significant \\
difference
\end{tabular} & Mn mg/L & $\begin{array}{c}5 \% \text { least } \\
\text { significant } \\
\text { difference }\end{array}$ & Zn mg/L & $\begin{array}{l}5 \% \text { least } \\
\text { significant } \\
\text { difference }\end{array}$ \\
\hline Chardonnay, Babadag & $0.794 \mathrm{e}$ & 0.468 & $1.006 \mathrm{~b}$ & 0.072 & $5.960 \mathrm{~d}$ & 1.000 \\
\hline Feteasca Neagra, Babadag & $1.380 \mathrm{de}$ & 0.085 & $0.934 \mathrm{c}$ & 0.134 & $7.622 \mathrm{~b}$ & 0.120 \\
\hline Feteasca Alba,Iasi & $3.144 \mathrm{c}$ & 0.345 & $0.668 \mathrm{~d}$ & 1.000 & $7.943 \mathrm{~b}$ & 0.120 \\
\hline Cabernet Sauvignon, lasi & 0.550 & 0.468 & $1.288 \mathrm{ab}$ & 0.394 & $2.633 \mathrm{f}$ & 0.963 \\
\hline Muscat ottonel, Blaj & $12.309 \quad a$ & 0.205 & $1.288 \mathrm{ab}$ & 0.394 & $10.041 \mathrm{a}$ & 1.000 \\
\hline Traminer roz, Blaj & $6.633 \mathrm{~b}$ & 1.000 & $1.346 \mathrm{a}$ & 0.322 & $7.030 \mathrm{c}$ & 1.000 \\
\hline Feteasca Alba,Stefanesti & $1.39 \mathrm{de}$ & 0.085 & $1.064 \mathrm{~b}$ & 0.072 & $3.722 \mathrm{e}$ & 0.083 \\
\hline Burgud, Stefanesti & $0.36 \mathrm{~cd}$ & 0.345 & $1.270 \mathrm{ab}$ & 0.394 & $2.642 \mathrm{f}$ & 0.963 \\
\hline Riesling, Stefanesti & 0.202 f & 0.205 & $1.206 \mathrm{~b}$ & 0.072 & $3.362 \mathrm{e}$ & 0.083 \\
\hline Feteasca Regala, Stefanesti & 0.288 f & 0.205 & $0.914 \mathrm{c}$ & 0.134 & $2.182 \mathrm{~g}$ & 1.000 \\
\hline
\end{tabular}

*Values with different letters are statistically different at 5\% probability, Duncan test

Heavy wine metals are expressed in $\mu \mathrm{g} / \mathrm{l}$, except for Fe, Mn and $\mathrm{Zn}$, expressed in $\mathrm{mg} / \mathrm{I}$ (Figure 2).

For the latter, along with the calculated value, we have the standard error, which gives us the degree of inaccuracies (error) to the two indicators, in relation to their real values, at the level of the population at which the analysed data is assumed to be extracted. The comparative boxplot representations of Figure 2 make the relationships between the distributions analysed, reporting simultaneously at the same reference value (Figure 2 ) and the values of heavy metals concentrations in the analysed wines.

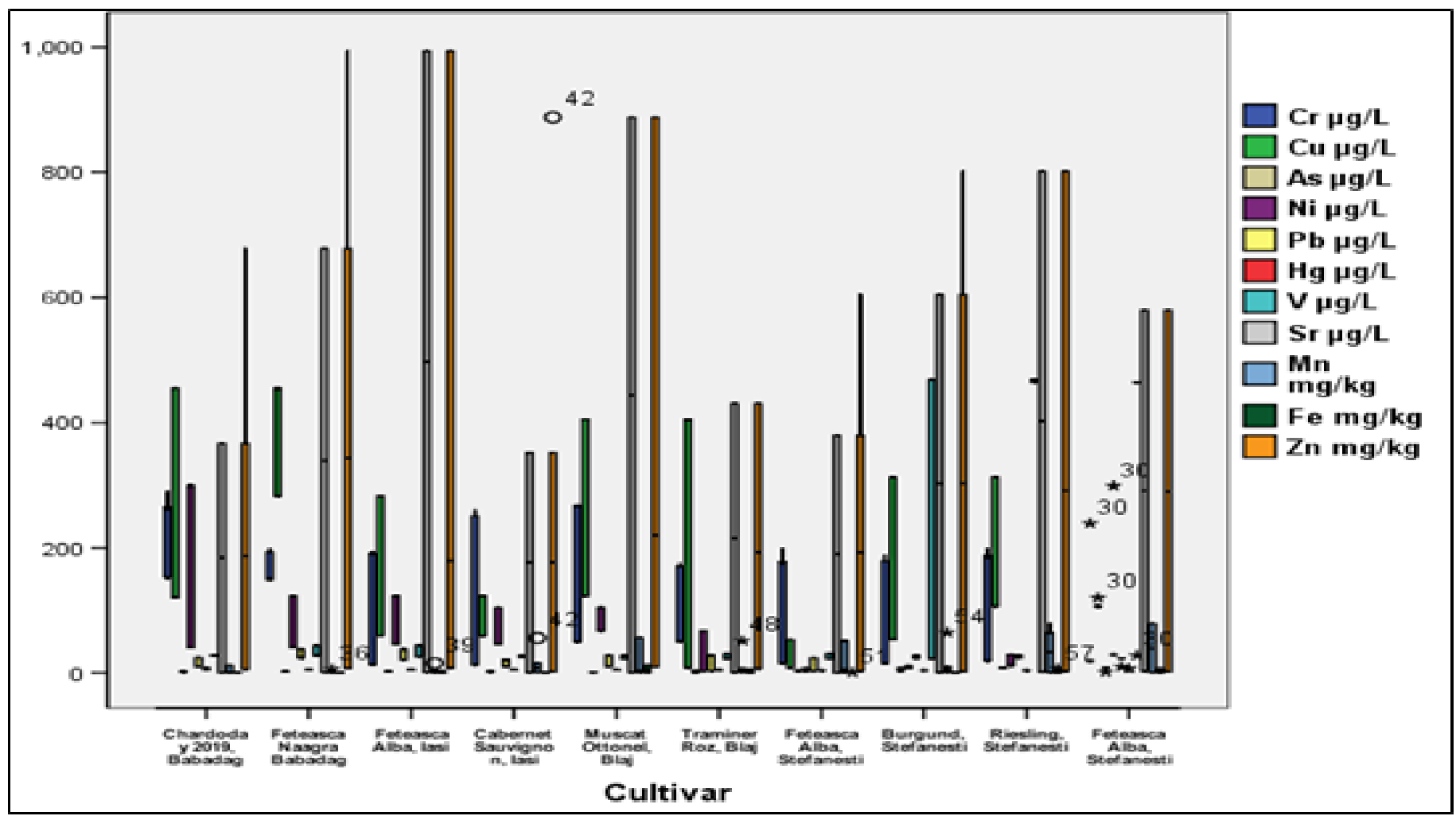

Figure 2. Heavy metals in wine

For the latter, along with the calculated value, we have the standard error, which gives us the degree of inaccuracies (error) to the two indicators, in relation to their real values, at the level of the population at which the analysed data is assumed to be extracted. The comparative boxplot representations of Figure 2 make the relationships between the distributions analysed, reporting simultaneously at the same reference value (Figure 2) and the values of heavy metals concentrations in the analysed wines. 


\section{Monitoring The Content of Heavy Metals in The Soil and Wines from Different Wine-Growing Areas of Romania}

Table 9. Results of Statistical Test to Check Normality for the Metals Analysed and the Gradations of the Wine Factor

\begin{tabular}{|c|c|c|c|c|c|c|}
\hline & \multicolumn{3}{|c|}{ Kolmogorov-Smirnov(a) } & \multicolumn{3}{|c|}{ Shapiro-Wilk } \\
\hline & Statistic & $\mathrm{df}$ & Sig. & Statistic & df & Sig. \\
\hline $\mathrm{Cr} \mu \mathrm{g} / \mathrm{L}$ & .209 & 60 & .000 & .854 & 60 & .000 \\
\hline $\mathrm{Cu} \mu \mathrm{g} / \mathrm{L}$ & .276 & 60 & .000 & .860 & 60 & .000 \\
\hline As $\mu \mathrm{g} / \mathrm{L}$ & .262 & 60 & .000 & .806 & 60 & .000 \\
\hline $\mathrm{Ni} \mu \mathrm{g} / \mathrm{L}$ & .229 & 60 & .000 & .721 & 60 & .000 \\
\hline $\mathrm{Pb} \mu \mathrm{g} / \mathrm{L}$ & .231 & 60 & .000 & .888 & 60 & .000 \\
\hline $\mathrm{Hg} \mu \mathrm{g} / \mathrm{L}$ & .239 & 60 & .000 & .701 & 60 & .000 \\
\hline $\mathrm{V} \mu \mathrm{g} / \mathrm{L}$ & .454 & 60 & .000 & .531 & 60 & .000 \\
\hline $\mathrm{Sr} \mu \mathrm{g} / \mathrm{L}$ & .310 & 60 & .000 & .804 & 60 & .000 \\
\hline $\mathrm{Mn} \mathrm{mg/kg}$ & .304 & 60 & .000 & .647 & 60 & .000 \\
\hline Fe $\mathrm{mg} / \mathrm{kg}$ & .368 & 60 & .000 & .629 & 60 & .000 \\
\hline $\mathrm{Zn} \mathrm{mg/kg}$ & .309 & 60 & .000 & .807 & 60 & .000 \\
\hline
\end{tabular}

In table 9, it is presented the results of statistical tests for normalization from the analysed metals and wine factor grades. Essentially, they test the degree of overlapping between the cumulative distribution of the variable analysed and the cumulative distribution of a variable whose distribution follows the Gaussian form.

Table 10 shows the statistical indicators of the central trend and distribution of the values of the indicators analysed for the 10 wines subjected to the tests throughout the sample: $\mathrm{N}$ (number of measured values and missing values); The minimum and maximum sample value, the maximum, medium, median and mode, standard deviation and asymmetry values and vault indicators (excess). For the latter, along with the calculated value, we have the standard error, which gives us the degree of inaccuracies (error) to the two indicators concerning their real values, at the level of the population at which the analysed data is assumed, is extracted. In our case, we notice that the normality test has P (sig.) Higher than 0.05 for the "heavy metal" variables, which confirms the normality hypothesis. The comparative boxplot representations of Figures 3 make the relations between the more expressive distributions, reported simultaneously at the same reference value (Figure 3 ), the values of heavy metals in the analysed wines.

Table 10. Statistical Indicators of the Central Trend and the Spread of Heavy Metal Values Analysed From Wines Studied

\begin{tabular}{|c|c|c|c|c|c|c|c|c|c|c|c|}
\hline & $\mathrm{Cr} \mu \mathrm{g} / \mathrm{L}$ & $\mathrm{Cu} \mu g / \mathrm{L}$ & As $\mu g / L$ & Ni $\mu g / L$ & $\mathrm{~Pb} \mu \mathrm{g} / \mathrm{L}$ & $\mathrm{Hg} \mu g / \mathrm{L}$ & $\mathrm{V}_{\mu g} / \mathrm{L}$ & $\mathrm{Sr} \mu g / \mathrm{L}$ & Mn mg/kg & Fe $\mathrm{mg} / \mathrm{kg}$ & Zn mg/kg \\
\hline Mean & 129.365 & 192.749 & 3.7167 & 68.9686 & 21.725 & 4.971 & 123.9709 & 304.311 & 16.9161 & 2.0782 & 309.8845 \\
\hline Median & 152.19 & 122.081 & 2.5385 & 40.5075 & 24.624 & 4.715 & 28.7715 & 177.753 & 1.482 & 0.7745 & 181.1225 \\
\hline Mode & $15.88(\mathbf{a})$ & $53.40(a)$ & $1.05(a)$ & $3.47(a)$ & $4.06(a)$ & $4.34(a)$ & $23.38(a)$ & $352.15(a)$ & 1.29 & $20(a)$ & $2.18(a)$ \\
\hline Std. Devia fion & 95.8001 & 151.3826 & 2.5263 & 79.9539 & 9.7064 & 0.857 & 181.8367 & 343.013 & 25.8851 & 323609 & 342.9337 \\
\hline Skewness & 0.004 & 0.531 & 0.984 & 1.974 & -0.399 & 1.997 & 1.408 & 0.616 & 1.47 & 2.162 & 0.59 \\
\hline $\begin{array}{l}\text { Std. Emor of } \\
\text { Skewness }\end{array}$ & 0.309 & 0.309 & 0.309 & 0.309 & 0.309 & 0.309 & 0.309 & 0.309 & 0.309 & 0.309 & 0.309 \\
\hline Kurtosis & -1.539 & -1.228 & -0.492 & 3.468 & -0.831 & 3.495 & -0.014 & -1.043 & 0.546 & 4.006 & -1.094 \\
\hline $\begin{array}{l}\text { Stl. Emor of } \\
\text { Kurtosis }\end{array}$ & 0.608 & 0.608 & 0.608 & 0.608 & 0.608 & 0.608 & 0.608 & 0.608 & 0.608 & 0.608 & 0.608 \\
\hline Range & 277.09 & 446.27 & 7.51 & 297.49 & 33.71 & 3.11 & 445.63 & 99322 & 78.33 & 12.63 & 991.11 \\
\hline Minimum & 12.26 & 8.63 & 1.04 & 3.46 & 4.05 & 4.34 & 23.24 & 0.07 & 0.67 & 0.02 & 2.18 \\
\hline Maximum & 289.35 & 454.9 & 8.55 & 300.95 & 37.76 & 7.45 & 468.87 & 99329 & 79 & 12.65 & 993.29 \\
\hline
\end{tabular}

In Table 11, the correlations between the indicators studied in wine show which we highlight below: it is noted that $\mathrm{Cr}$ element correlates positively with the elements: $\mathrm{Cu}, \mathrm{Sr}, \mathrm{Mn}$ and $\mathrm{Zn}(\mathrm{r}=0.12, r=0.062, r=0.003, r=0.099)$, distinctly significantly positive with the elements $\mathrm{Ni}, \mathrm{Hg}\left(r=0.552^{* *}, r=0.499^{* *}\right)$ and negative correlation with $\mathrm{V}, \mathrm{Fe}(\mathrm{r}=-0.165, r=-0.054)$, significantly negative with As $\left(r=-0.265^{*}\right)$ and distinctly significantly negative with $\mathrm{Pb}$ element $\left(r=-0.378^{* *}\right)$, which explains that there is a balanced ratio between these indicators (Grindlay et al, 2009; Woldemariam, 2011; Bora et al, 2015; Zava et al, 2020). 
The Hg element was correlated positively with $\mathrm{Cu}$ and $\mathrm{Sr}(\mathrm{r}=0.144, \mathrm{r}=0.003)$, distinctly positive with $\mathrm{Ni}$ and $\mathrm{Cr}(\mathrm{r}=0.902 * *, \mathrm{r}=0$. 499**), and on the other hand negative correlation with $\mathrm{Pb}, \mathrm{Zn}$ and $\mathrm{Fe}(\mathrm{r}=-0.173, \mathrm{r}=-0.208, \mathrm{r}=-0.084)$, distinctly significant and significantly negative correlations with $A s, V$ and $\mathrm{Mn}\left(r=-0.475^{* *}, r=-0.372^{* *}, r=-0.298^{*}\right)$. The Sr element is positively correlated with the elements: $\mathrm{Cr}, \mathrm{Ni}, \mathrm{Cu}, \mathrm{Pb}, \mathrm{Hg}, \mathrm{V}(\mathrm{r}=0.065, \mathrm{r}=0.034, \mathrm{r}=0.083, \mathrm{r}=0.124, \mathrm{r}=0.003, \mathrm{r}=0.031)$, significantly positive with the Fe element $\left(r=0.325^{*}\right)$ and distinctly significant negative correlated with $\mathrm{Mn}$ and $\mathrm{Zn}\left(\mathrm{r}=-0.549 * *, r=-0.797^{* *}\right)$.

Table 11. Correlations between the Elements Studied In Wine Cultivars

\begin{tabular}{|c|c|c|c|c|c|c|c|c|c|c|c|c|}
\hline & & $\mathrm{Cr} \mu \mathrm{g} / \mathrm{L}$ & $\mathrm{Ni} \mu \mathrm{g} / \mathrm{L}$ & $\mathrm{Cu} \mu \mathrm{g} / \mathrm{L}$ & As $\mu \mathrm{g} / \mathrm{L}$ & $\mathrm{Pb} \mu \mathrm{g} / \mathrm{L}$ & $\mathrm{Hg} \mu \mathrm{g} / \mathrm{L}$ & $\vee \mu g / L$ & $\mathrm{Sr} \mu \mathrm{g} / \mathrm{L}$ & $\begin{array}{c}\mathrm{Mn} \\
\mathrm{mg} / \mathrm{kg}\end{array}$ & $\begin{array}{c}\mathrm{Fe} \\
\mathrm{mg} / \mathrm{kg}\end{array}$ & $\begin{array}{c}\mathrm{Zn} \\
\mathrm{mg} / \mathrm{kg}\end{array}$ \\
\hline \multirow[t]{2}{*}{$\mathrm{Cr} \mu \mathrm{g} / \mathrm{L}$} & $\begin{array}{l}\text { Pearson } \\
\text { Correlatio } \\
n\end{array}$ & 1 & $.552\left({ }^{* *}\right)$ & 0.12 & $-.265\left(^{*}\right)$ & $-.378\left({ }^{* \star}\right)$ & $499\left(^{* *}\right)$ & -0.165 & 0.062 & 0.003 & -0.054 & 0.099 \\
\hline & $\begin{array}{l}\text { Sig. (2- } \\
\text { tailed) }\end{array}$ & & o & 0.362 & 0.041 & 0.003 & 0 & 0.207 & 0.638 & 0.984 & 0.683 & 0.449 \\
\hline \multirow[t]{2}{*}{$\mathrm{Ni} \mu \mathrm{g} / \mathrm{L}$} & $\begin{array}{l}\text { Pearson } \\
\text { Correlatio } \\
\text { n }\end{array}$ & $.552\left({ }^{\star \star}\right)$ & 1 & 0.014 & $-468\left({ }^{* *}\right)$ & -0.183 & $\left..9022^{* *}\right)$ & $-.307\left(^{*}\right)$ & 0.034 & -0.197 & -0.062 & -0.043 \\
\hline & $\begin{array}{l}\text { Sig. (2- } \\
\text { tailed) }\end{array}$ & 0 & & 0.917 & 0 & 0.162 & 0 & 0.017 & 0.797 & 0.131 & 0.636 & 0.745 \\
\hline \multirow[t]{2}{*}{$\mathrm{Cu} \mu \mathrm{g} / \mathrm{L}$} & $\begin{array}{l}\text { Pearson } \\
\text { Correlatio } \\
\text { n }\end{array}$ & 0.12 & 0.014 & 1 & -0.193 & $.595\left(^{\star *}\right)$ & 0.144 & 0.037 & 0.083 & -0.211 & -0.024 & 0.109 \\
\hline & $\begin{array}{l}\text { Sig. (2- } \\
\text { tailed) }\end{array}$ & 0.362 & 0.917 & & 0.14 & 0 & 0.273 & 0.781 & 0.527 & 0.105 & 0.856 & 0.409 \\
\hline \multirow[t]{2}{*}{ As $\mu \mathrm{g} / \mathrm{L}$} & $\begin{array}{l}\text { Pearson } \\
\text { Correlatio } \\
n\end{array}$ & $-.265\left(^{*}\right)$ & $-468\left({ }^{* \pi}\right)$ & -0.193 & 1 & 0.134 & $-475\left(^{* *}\right)$ & $.928\left(^{\star \star *}\right)$ & -0.008 & $\left.4700^{* *}\right)$ & 0.013 & 0.057 \\
\hline & $\begin{array}{l}\text { Sig. (2- } \\
\text { tailed) }\end{array}$ & 0.041 & o & 0.14 & & 0.308 & 0 & 0 & 0.951 & 0 & 0.923 & 0.665 \\
\hline \multirow[t]{2}{*}{$\mathrm{Pb} \mu \mathrm{g} / \mathrm{L}$} & $\begin{array}{l}\text { Pearson } \\
\text { Correlatio } \\
\text { n }\end{array}$ & $-.378(\star *)$ & -0.183 & $.595\left(^{\star *}\right)$ & 0.134 & 1 & -0.173 & $255\left(^{*}\right)$ & 0.124 & -0.152 & -0.073 & 0.162 \\
\hline & $\begin{array}{l}\text { Sig. (2- } \\
\text { tailed) }\end{array}$ & 0.003 & 0.162 & 0 & 0.308 & & 0.187 & 0.05 & 0.345 & 0.247 & 0.578 & 0.215 \\
\hline \multirow[t]{2}{*}{$\mathrm{Hg} \mu \mathrm{g} / \mathrm{L}$} & $\begin{array}{l}\text { Pearson } \\
\text { Correlatio } \\
n\end{array}$ & $499\left(^{(\star \star}\right)$ & $.902\left(^{\star *}\right)$ & 0.144 & $-.475\left(^{\star \star}\right)$ & -0.173 & 1 & $-372\left({ }^{\star *}\right)$ & 0.003 & $-.298\left(^{*}\right)$ & -0.208 & -0.084 \\
\hline & $\begin{array}{l}\text { Sig. (2- } \\
\text { tailed) }\end{array}$ & 0 & 0 & 0.273 & 0 & 0.187 & & 0.003 & 0.981 & 0.021 & 0.111 & 0.525 \\
\hline \multirow[t]{2}{*}{$\vee \mu g / L$} & $\begin{array}{l}\text { Pearson } \\
\text { Correlatio } \\
n\end{array}$ & -0.165 & $-.307\left(^{\star}\right)$ & 0.037 & $.928\left({ }^{* *}\right)$ & $255\left(^{\star}\right)$ & $-.372(* \star)$ & 1 & 0.031 & $.467\left(^{\star \star}\right)$ & 0.067 & 0.09 \\
\hline & $\begin{array}{l}\text { Sig. (2- } \\
\text { tailed) }\end{array}$ & 0.207 & 0.017 & 0.781 & 0 & 0.05 & 0.003 & & 0.813 & 0 & 0.609 & 0.493 \\
\hline \multirow[t]{2}{*}{$\mathrm{Sr} \mu \mathrm{g} / \mathrm{L}$} & $\begin{array}{l}\text { Pearson } \\
\text { Correlatio } \\
n\end{array}$ & 0.062 & 0.034 & 0.083 & -0.008 & 0.124 & 0.003 & 0.031 & 1 & $-.549\left(^{\star \star}\right)$ & $.325\left(^{*}\right)$ & $-.797\left(^{\star \star}\right)$ \\
\hline & $\begin{array}{l}\text { Sig. (2- } \\
\text { tailed) }\end{array}$ & 0.638 & 0.797 & 0.527 & 0.951 & 0.345 & 0.981 & 0.813 & & o & 0.011 & o \\
\hline \multirow[t]{2}{*}{$\begin{array}{l}\mathrm{Mn} \\
\mathrm{mg} / \mathrm{kg}\end{array}$} & $\begin{array}{l}\text { Pearson } \\
\text { Correlatio } \\
n\end{array}$ & 0.003 & -0.197 & -0.211 & $.470\left({ }^{* *}\right)$ & -0.152 & $-.298\left(^{*}\right)$ & $467\left(^{\star \star *}\right)$ & $-.549\left(^{\star \star}\right)$ & 1 & 0.16 & $.589\left(^{\star \star *}\right)$ \\
\hline & $\begin{array}{l}\text { Sig. (2- } \\
\text { tailed) }\end{array}$ & 0.984 & 0.131 & 0.105 & 0 & 0.247 & 0.021 & 0 & 0 & & 0.223 & 0 \\
\hline \multirow[t]{2}{*}{$\begin{array}{l}\mathrm{Fe} \\
\mathrm{mg} / \mathrm{kg}\end{array}$} & $\begin{array}{l}\text { Pearson } \\
\text { Correlatio } \\
n\end{array}$ & -0.054 & -0.062 & -0.024 & 0.013 & -0.073 & -0.208 & 0.067 & $.325\left(^{*}\right)$ & 0.16 & 1 & -0.198 \\
\hline & $\begin{array}{l}\text { Sig. (2- } \\
\text { tailed) }\end{array}$ & 0.683 & 0.636 & 0.856 & 0.923 & 0.578 & 0.111 & 0.609 & 0.011 & 0.223 & & 0.13 \\
\hline \multirow[t]{2}{*}{$\begin{array}{l}\mathrm{Zn} \\
\mathrm{mg} / \mathrm{kg}\end{array}$} & $\begin{array}{l}\text { Pearson } \\
\text { Correlatio } \\
\text { n }\end{array}$ & 0.099 & -0.043 & 0.109 & 0.057 & 0.162 & -0.084 & 0.09 & $-.797\left(^{* *}\right)$ & $\left..5899^{* *}\right)$ & -0.198 & 1 \\
\hline & $\begin{array}{l}\text { Sig. (2- } \\
\text { tailed) }\end{array}$ & 0.449 & 0.745 & 0.409 & 0.665 & 0.215 & 0.525 & 0.493 & o & o & 0.13 & \\
\hline
\end{tabular}

\section{CONCLUSIONS}

Intensive wine production from lasi viticulture area had like results an increase of $\mathrm{Cu}$ content in the soil, about tens of times larger $(135,455 \mu \mathrm{g} / \mathrm{kg}$ ) as compared to the other wine-producing geographical areas (Babadag vineyard $-0,120 \mu \mathrm{g} / \mathrm{l}$ ), due to cultural practice on the ancestors of wine production and regarding the long term of treatments application with copper products.

The high concentration of $\mathrm{Pb}$ in soil $(19,76 \mathrm{mg} / \mathrm{kg})$, it is from Blaj geographic area, due to the pollution from the industry in the area and proximity to the A10 highway; this leads to a Pb content of the wine to being larger (Fetească Neagră - 24,99 $\mu$ I); but the highest value is found in wine from lasi viticulture region (Fetească Albă - 37,76 $\mu \mathrm{g} / \mathrm{l}$ ), although the Pb content in soil is lower there $(5,073 \mathrm{mg} / \mathrm{kg})$, due to the treatments performed on vines it is higher in wine. However, the other concentrations of 


\section{Monitoring The Content of Heavy Metals in The Soil and Wines from Different Wine-Growing Areas of Romania}

toxic metal lead in wines were found in the range of $0,02-37,76 \mu \mathrm{g} / \mathrm{l}$; These values are quite low compared to the set limit of OIV as $0,2 \mathrm{mg} / \mathrm{l}$.

The elements $\mathrm{Cr}, \mathrm{Ni}, \mathrm{Sr}, \mathrm{Cu}, \mathrm{Pb}, \mathrm{Hg}$ and $\mathrm{V}$ were identified as indicators for the description of wines and soils for the four geographical areas studied. Concentration levels of all analysed elements in all examined wine samples were below the maximum contamination level established by O.I.V. regulations. In general, moderate wine consumption contributes to the daily nutritional requirements of many essential metals, including $\mathrm{Fe}, \mathrm{Zn}, \mathrm{Mn}$, and $\mathrm{Cu}$. The elements $\mathrm{As}, \mathrm{V}, \mathrm{Pb}, \mathrm{Hg}, \mathrm{Cr}, \mathrm{Ni}, \mathrm{Mn}, \mathrm{Zn}$ were found to have a significant mutual correlation in analysed wines. They were also found to differ between the four wine-growing regions investigated. Since $\mathrm{Sr}, \mathrm{Hg}, \mathrm{Mn}$ are typical geological elements, their presence in wine is normally considered to reflect regional soil chemistry. The association of $\mathrm{Pb}$ and $\mathrm{As}$ with geological elements involves a predominant feature. In general, the values found are in line with the data previously reported on wines from another bibliographic source, a natural condition for these elements.

\section{REFERENCES}

1) Alkıs Mert I., Oz S., Atakol A., Yılmaz N., Ertan Anlı R., Atakol O., "Investigation of heavy metal concentrations in some Turkish wines", Journal of Food Composition and Analysis 33, 2014, 105-110, http://dx.doi.org/10.1016/j.jfca.2013.11.006.

2) Almeida, C. M. R., \& Vasconcelos, M. T. S. D., "Multielement composition of wines and their precursors including provenance soil and their potentialities as fingerprints of wine origin", Journal of Agricultural Food Chemistry, 2003, 51(16), 4788-4798. http://dx.doi.org/10.1016/j.foodchem.2008.05.043.

3) Arvanitoyannis, S., Katsota, M. N., Psarra, E. P., Soufleros, E. H. and Kallithraka, S., "Application of quality control methods for assessing wine authenticity: use of multivariate analysis (chemometrics)," Trends in Food Science and Technology, 1999, vol. 10, no. 10, pp. 321-336. . http://dx.doi.org/10.1016/S0924-2244(99)00053-9.

4) Bora, F.D., Bunea, C.I., Rusu, T. and Pop, N., "Vertical distribution and analysis of micro-, macroelements and heavy metals in the system soil-grapevine-wine in vineyard from North-West Romania", Chemistry Central Journal, 2015, vol. 9:19, DOI 10.1186/s13065-015-0095-2.

5) Bora, F.D., Bunea, C., 2019. Bioacumularea metalelor în vița-de-vie. Editura Bioflux, Cluj-Napoca. elSBN 978-606-888755-5

6) Boschetti, W., Rampazzo, R. T., Dessuy M. B. et al., "Detection of the origin of Brazilian wines based on the determination of only four elements using high-resolution continuum source flame AAS", Talanta, 2013, vol. 111, pp. 147-155.

7) Catarino Sofia, Capelo J.L., Curvelo-Garcia A.S. and De Sousa R.B., "Evaluation of contaminant elements in Portuguese wines and original musts by high intensity focused ultrasound combined with inductively coupled plasma mass spectrometry", Journal International, Science Vigne Vin, 2006, 40, no 2, pg. 91-101.

8) Cetó, X., Gutiérrez, J. M., Gutiérrez, M. et al., "Determination of total polyphenol index in wines employing a voltammetric electronic tongue", Analytica Chimica Acta, 2012, vol. 732, pp. 172-179.

9) Coetzee, P. P., Steffens, F. E., Eiselen, R. J., Augustyn, O. P., Balcaen, L., \& Vanhaecke, F. "Multi-element analysis of South African wines by ICP-MS and their classification according to geographical origin", Journal of Agricultural Food Chemistry, 2005, 52(13), 5060-5066 http://dx.doi.org/10.1021/jf048268n

10) Danezis G., Tsagkaris A., Brusic V., Georgiou C., "Food authentication: state of the art and prospects", Curr. Opin. Food Science, 2016, vol.10, pp. 22-31.

11) Dugo, G., La Pera, L., Pellicanó, T. M., Di Bella, G. and D'Imperio, M., “Determination of some inorganic anions and heavy metals in D.O.C. Golden and Amber Marsala wines: statistical study of the influence of ageing period, colour and sugar content", Food Chemistry, 2015, vol. 91, no. 2, pp. 355-363.

12) De Villiers, A., Vanhoenacker, G., Majek, P. and Sandra, P., "Determination of anthocyanins in wine by direct injection liquid chromatography-diode array detection-mass spectrometry and classification of wines using discriminant analysis", Journal of Chromatography A, 2004, vol. 1054, no. 1-2, pp. 195-204.

13) Everstine K., Spink J., Kennedy S., "Economically motivated adulteration (EMA) of food: common characteristics of EMA incidents", Journal of Food Protection, 2013, vol. 76, pp. 723-735.

14) Fabani, M. P., Ravera, M. J. A. and Wunderlin, D. A. "Markers of typical red wine varieties from the Valley of Tulum (San Juan-Argentina) based on VOCs profile and chemometrics," Food Chemistry, 2013, vol. 141, no. 2, pp. $1055-1062$.

15) Fiket, Z, Mikac, N, Kniewald, G. "Arsenic and other trace elements in wines of eastern Croatia", Journal of Food Chemistry, 2011, vol.126, pp. 941-947. 
16) Franquet-Griell, H., Checa, A., Núñez, O., Saurina, J., Hernández-Cassou, S. and Puignou, L., “Determination of polyphenols in spanish wines by capillary zone electrophoresis. Application to wine characterization by using chemometrics", Journal of Agricultural and Food Chemistry, 2012, vol. 60, no. 34, pp. 8340-8349.

17) Gallagher, L. T., Heo, J. S., Lopez, M. A. et al., "Pattern-based discrimination of organic acids and red wine varietals by arrays of synthetic receptors", Supramolecular Chemistry, 2012, vol. 24(2), pp. 143-148

18) Geana,I., lordache, A., lonete, R., Marinescu, A., Ranca, A., Culea M., "Geographical origin identification of Romanian wines by ICP-MS elemental analysis", Journal of Agricultural Food Chemistry, 2013, vol. 138, pp. 1125-1134, Available: https://www.journals.elsevier.com/food-chemistry

19) Gogoașă, I., Maruțoiu, C., Gergen, I., Rada, M., Tigae, C., "The use of vegetables as indicators in determining the environment pollution", Rev Chim., 2005, Vol. 56, pp.1275-1276.

20) Goamez Maria del Mar Casteneira, Brandt R., Jakubowski N., Andersson J.T., "Changes of the metal composition in German white wines through the winemaking process. A study of 63 elements by inductively coupled plasma-mass spectrometry", Journal Agricultural and Food Chemistry, 2004, 52, 2953-2961

21) Grindlay G., Moraa J., Gras L., de Loos-Vollebregt Margaretha T.C., "Ultratrace determination of Pb, Se and As in wine samples by electrothermal vaporization inductively coupled plasma mass spectrometry", Analytica Chimica Acta, doi:10.1016/j.aca.2009.05.020

22) Grindlay G., Moraa J., Gras L., de Loos-Vollebregt Margaretha T.C., "Atomic spectrometry methods for wine analysis: A critical evaluation and discussion of recent applications", Analitica Chimica Acta, 2011, pg 15, doi:10.1016/j.aca.2011.02.050

23) Héberger, K., Csomós, E. and Simon-Sarkadi, L., "Principal component and linear discriminant analyses of free amino acids and biogenic amines in Hungarian wines", Journal of Agricultural and Food Chemistry, 2003, vol. 51, no. 27, pp. 8055-8060.

24) Huang, X. Y., Jiang, Z. T., Tan, J., Li, R., “Geographical Origin Traceability of Red Wines Based on Chemometric Classification via Organic Acid Profiles", Journal of Food Quality, vol. 2017, Article ID 2038073, 7 pages, https://doi.org/10.1155/2017/2038073.

25) Huzum, R, lancu, O.G., Buzgar, N., "Geochemical distribution of selected trace elements in vineyard soils from the Huşi area, Romania", Carpath J Earth Environ Science, 2012, vol.7 (3), pp.61-70.

26) Jakubowski N., Brandt R., Stuewer D., Eschnauer H.R., Görtges S., "Analysis of wines by ICP-MS: Is the pattern of the rare earth elements a reliable fingerprint for the provenance?", Fresenius Journal Analitical Chemistry, 1999, 364, pg.424-428

27) Kiss, J. and Sass-Kiss, A., "Protection of originality of Tokaji Aszú: amines and organic acids in botrytized wines by highperformance liquid chromatography", Journal of Agricultural and Food Chemistry, 2005, vol. 53, no. 26, pp. 1004210050.

28) Košir, I. J., Lapornik, B., Andrenšek, S., Wondra, A. G., Vrhovšek, U. and Kidrič, J., "Identification of anthocyanins in wines by liquid chromatography, liquid chromatography-mass spectrometry and nuclear magnetic resonance", Analytica Chimica Acta, 2014, vol. 513, no. 1, pp. 277-282.

29) Kostic,D, Mitic, S, Miletic, G, Despotovic, S, Zarubica, A., "The concentrations of Fe, Cu and Zn in selected wines from South-East Serbia", Journal of Serb Chemistry Society, 2010, vol. 75(12), pp. 1701-1709.

30) di Paola-Naranjo Romina D., Baroni María V., Podio Natalia S., Rubinstein H.R., Fabani María P., Badini R.G., Inga Marcela, Ostera H. A., Cagnoni Mariana, Gallegos E., Gautier E., García Pilar Peral, Hoogewerff H and Wunderlin D.A., „Fingerprints for main varieties of Argentinean wines: Terroir differentiation by inorganic, organic, and stable isotopic analyses coupled to chemometrics", Journal Agricultural and Food Chemistry, 2011, 59, 7854-7865, dx.doi.org/10.1021/jf2007419

31) Petropulos, Violeta Ivanova, Wiltsche, H., Stafilov, T., Stefova, Marina, Motter H., Lankmayr, E., „Multielement analysis of Macedonian wines by inductively coupled plasma-mass spectrometry (ICP-MS) and inductively coupled plasmaoptical emission spectrometry (ICP-OES) for their classification“, Macedonian Journal of Chemistry and Chemical Engineering, 2013, Vol. 32, No. 2, pp. 265-281

32) Regmi, U., Palma, M. and Barroso, C.G, "Direct determination of organic acids in wine and wine-derived products by Fourier transform infrared spectroscopy and chemometric techniques", Analytica Chimica Acta, 2012, vol. 732, pp. 137-144 
33) Serrano-Lourido D, Saurina, J, Hernández-Cassou, S. and Checa, A., "Classification and characterisation of Spanish red wines according to their appellation of origin based on chromatographic profiles and chemometric data analysis", Food Chemistry, 2012, vol. 135, no. 3, pp. 1425-1431.

34) Tariba B. "Metals in wine-impact on wine quality and health outcomes", Biol Trace Elem Res, 2011, vol.144, pp.143-56

35) Tuzen, M, Soylak, M., "Evaluation of trace element contents in canned foods marketed from Turkey", Food Chem, 2007, vol. 102, pp. 1089-1095.

36) Toti M., Dumitru M., Vlad V., Calciu, Irina. 2017. Solul - element de bază al conceptului "Terroir", Ed. Terra Nostra, Iași

37) Zava, A., Sebastião, P. J., Catarino, S., "Wine traceability and authenticity: Approaches for geographical origin, variety and vintage assessment", Journal of Ciência e Técnica Vitivinícola, 2020, vol. 35(2), pp. 133-147. https://www.researchgate.net/publication

38) 38). Woldemariam, D.M. and Chandravanshi, B.S., "Concentration levels of essential and non-essential elements in selected Ethiopian wines", Bulletin Chemistry Society Ethiopian, 2011, 25(2), 169-180. 